and reference made to the peculiar properties of certain substances at low temperatures. Prof. M. Polanyi, professor of physical chemistry in the University of Manchester, gave the second lecture, his subject being "Reaction Velocity and Thermodynamics". He discussed the general effect of pressure on the velocity of chemical reactions, using relations deduced in accordance with thermodynamical principles, and referred among other things to the alteration of the equilibrium of reactions due to pressure, the grouping of reactions, and the connexion between reaction velocity and the heat of reaction. $\mathrm{He}$ also described recent work on the mechanism of ionogenic reactions. The lectures were well supported by members and friends, and were followed by helpful discussions of the various points raised.

\section{Chemical Industry and Water Problems}

THE presidential address of Mr. Edwin Thompson, at the annual general meeting of the Society of Chemical Industry at Glasgow on July 2, dealt with the question of water supply in Great Britain and covered a wide range of topics in that connexion. Mr. Thompson considered the problem of a national water policy to call for immediate investigation. $\mathrm{He}$ deplored the spirit of localism which still manifests itself in connexion with every water supply scheme of magnitude, despite the recommendation made nearly seventy years ago by the Royal Commission of 1868 "that no town should be allowed to appropriate a source of supply which naturally and geographically belongs to a town or district nearer to such source, unless under special eircumstances which justify the appropriation". He said there is too much selfishness among water undertakings, and that they could do much to relieve the needs of those who have no water supply. He went on to discuss a number of difficulties and problems which are associated with questions of supply : water pollution, rural requirements, misuse and waste of water, the increase during recent years of the per capita consumption, diversion of supplies for canals, storage reservoirs, biological factors of storage, sewage effluents into rivers, compensation water, etc. He alluded to and endorsed the necessity for a survey of the water resources of Great Britain and instanced from the report of the British Association Committee the example set in this respect by other nations. The idea of a water grid was dismissed. The valuation of waterworks for rating purposes has a serious financial bearing on the administration and working expenses of an undertaking. The formation of a Select Committee of the Houses of Parliament to go fully into the question of national water supplies made him confident that the anxieties and hardships of the past year will never be repeated.

\section{The Annual Tables of Constants}

AT the conference of the International Union of Chemistry, held in April 1934 in Madrid, it was recommended that a substantial part of the funds at the disposal of the Union should be transferred to the International Committee of Annual Tables of
Constants, in order to assist in the publication of these valuable tables. This recommendation was passed unanimously by the Union's executive in Paris in last October and confirmed by the national organisations representing the various countries adhering to the Union, such as Verband Deutscher Chemischer Vereine representing Germany, Comité National Belge de Chimie representing Belgium, National Research Council, Division of Chemistry, representing the United States, and so on. The sum thus put at the disposal of the Committee of the Annual Tables is 150,000 franes; the amount indicates the importance which international chemical circles attach to the continuation of the Annual Tables. This sum will be used up for printing the index of the second series (vol. 6-10, 1923-1930), which is now ready. In return for this gift, the Committee of the Annual Tables is going to put at the disposal of the chemical organisations adhering to the Union a certain number of complete sets of the Tables.

\section{Atmospheric Pollution}

THE twentieth report on atmospheric pollution issued by the Department of Scientific and Industrial Research (H.M.S.O., 5s. net) records observations for the year ending March 31, 1934. This report, like its forerunners, shows that preconceived notions are not always supported by measurement. If the conditions of sampling and test are valid, then the City of London has the most polluted atmosphere observed in Great Britain, and deposits of solids and tar show annual increase. Again, foggy weather, judged by measurement of 'smoke haze', appears to reach greatest prevalence in Westminster, and some of the highest figures for sulphur pollution are also found in London observing stations. Some so-called industrial cities apparently have atmospheric conditions much superior to those in London. London may, however, take comfort from the fact that comparable measurements show that atmospheric pollution in Philadelphia is almost twice as bad. Experience is recorded with the use of a 'candle' of lead dioxide for measuring atmospheric sulphur compounds. Another interesting apparatus has been devised for recording the quantity of light. The light received by a photo-electric cell develops a current which imparts to a condenser a charge. When this reaches a certain amount, it discharges through a neon lamp and causes an ordinary counter to advance one unit. The difference between the records at the various stations is great, and it may be inferred that large improvements in atmospheric conditions are possible by using experience already known.

\section{Epidemic of Green Fly}

Wre learn from the Ministry of Agriculture and Fisheries that, in many districts in the southern half of England, oats have suffered from severe infestations by aphides or 'green fly'. Similar attacks on grassland have taken place in certain northern counties, ineluding Lancashire. The insects occurred often in swarms, smothering the crops and causing 
much damage. The species concerned is a common one which often causes local and temporary injury to grass. Its appearance in epidemic form on cereals is quite unique in recent times. The reasons for the outbreak are unknown, but they are probably associated with the relatively mild autumn and winter and the advanced condition of the crops. The standard control method would be the application of an insecticidal dust by means of a powder sprayer. The necessary equipment, however, is not available on many farms, and expenditure to meet this treatment seems scarcely justifiable in view of the damage that has already been done. It is probable that the aphids will shortly migrate, while natural enemies are already actively at work.

\section{Metals in Food}

THE Society of Public Analysts has issued a useful "Bibliography of the More Important Heavy Metals occurring in Food and Biological Material", the period covered being the years 1921-33. The elements dealt with are antimony, bismuth, cadmium, chromium, cobalt, copper, lead, manganese, mercury, nickel, thallium, tin and zinc. Each reference indicates the nature of the information to be found in the paper. The largest sections deal with copper, lead and manganese, which account for half the references quoted. The pamphlet (30 pages) can be obtained from the Editor of the Analyst, 85 Eccleston Square, London, S.W.1 (2s. to members of the Society; $3 s$. to non-members).

\section{Principles and Design of Precision Gauges}

IN these days of motor-cars, electric fittings and so on, everyone learns something of the value of interchangeability of parts and also experiences the disadvantage of finding that a part 'will not fit'. The progress of manufacture, indeed, depends largely on parts being interchangeable, and in mass production it is absolutely necessary to place limits on the permissible variation from standard dimensions. This necessity has given rise to the system of working to gauges, a system which received a great impetus through the manufacture of vast quantities of munitions during the War, and which to-day is perhaps used most extensively in the manufacture of motor-car engines and other parts. From being a comparative novelty, gauging has become a matter of ordinary routine, while the making and testing of gauges has itself become an industry. There will thus be many persons who will be able to appreciate the pamphlet of Mr. R. J. Foster on "The Principle and Design of Precision Gauges for Interchangeability" recently issued by the Association of Engineering and Ship-building Draughtsmen, and published by the Draughtsman Publishing Co., Ltd. (2s.). In this the reader will find sections on tolerances and fits and limits, plug gauges, pin gauges, external and internal gauges, height and depth gauges and comparators, together with many sketches and useful notes.

\section{International Geological Congress}

Premiminary arrangements are announced from Moscow for the meetings of the Seventeenth International Geological Cingress. which is to be held in the U.S.S.R. during the summer of 1937, the year of the twentieth anniversary of the Soviet Government. It is proposed that the first half of August should be devoted to the sessional meetings. The special topics suggested for discussion include petroleum, coal, ore-deposits, rare elements, geophysical methods, the Permian system, tectonic and geochemical problems, the relationship of magmatic rocks and ore-deposits to tectonics, and the history of geological knowledge. Three series of excursions, $A, B$ and $C$, are provisionally arranged, to take place respectively before, during and after the sessions, the whole programme extending from the beginning of July to the end of September. The $A$ series includes excursions to the north (Pre-Cambrian and Khibina Complex); the Urals ; the south (Crimea and Donets Basin); the Volga Basin ; and the Caucasus. The $C$ series are on a larger scale and cover very wide regions. They are described as petroleum and stratigraphical (main oil districts and Central Asia); Central Asia (stratigraphy, tectonics and volcanic phenomena; transcontinental (stratigraphy, tectonics and economic geology of Urals to Soviet Far East); and Turkestan-Siberia (Perm, Altai and Kuznetsk). More detailed descriptions will be given later. Meanwhile inquiries are invited and should be addressed to the Organisation Committee of the Seventeenth International Geological Congress, Moscow, 4, KoteInicheskaya, Naberezhnaya, 17.

\section{A Recent Sunspot}

A FAIRLy large group of sunspots has recently been visible whilst crossing the sun's disc on June 23-July 6 in long. $305^{\circ}$ and lat. $24^{\circ} \mathrm{S}$. Its area on June 28 was 1000 millionths of the sun's hemisphere, of which 850 millionths was the area of the leader spot. When near central meridian passage, which occurred on June $29 \cdot 9$, the group was visible to the naked eye. Though itself not a return of an individual spot of the previous rotation, the recent spot represented a continuation of localised disturbance which has been apparent for the last two months in this part of the solar surface. In an ordinary telescope, the group has been an interesting object with conspicuous 'bridges' across the leader spot in particular. The spectroscope offered, as usual, a further range of observation. On June 26 at $8^{\mathrm{h}} 45^{\mathrm{m}}$ G.M.T. a bright eruption took place that was observable visually in the hydrogen $C$ line of the solar spectrum and should have been possible to photographic records in the $H$ and $K$ lines of ionised calcium. The spectrohelioscope showed with perfection the contour of the areas of the brilliant hydrogen $(\mathrm{H} \alpha)$ emission and the dark filaments of gas bordering them at a later stage. The largest radial velocities measured at Greenwich for the absorption filaments were $20 \mathrm{~km}$. a sec. outwards and $60 \mathrm{~km}$. a sec. inwards to the sun. On June 29 at about $8^{\mathrm{h}} 45^{\mathrm{m}}$, several moderately large radial

(Continued on p. 27.) 